\title{
PROCLUS
}

A COMMENTARY ON THE

FIRST BOOK OF

EUCLID'S ELEMENTS 



\title{
PROCLUS
}

\section{A COMMENTARY ON THE FIRST BOOK OF}

\section{EUCLID'S ELEMENTS}

\author{
Translated \\ with Introduction and Notes by \\ GLENN R. MORROW \\ Adam Seybert Professor Emeritus \\ of Moral and Intellectual Philosophy \\ University of Pennsylvania
}

PRINCETON UNIVERSITY PRESS 1970

PRINCETON, NEW JERSEY 
Published by Princeton University Press, 41 William Street,

Princeton, New Jersey 08540

In the United Kingdom, by Princeton University Press, Oxford

Copyright (C) 1970 by Princeton University Press

Foreword to the 1992 edition (C) 1992 by Princeton University Press

All Rights Reserved

Library of Congress Card No. 73-90955

Library of Congress Cataloging-in-Publication Data

Proclus, ca. 410-485.

[Eis prōton Eukleidou stoicheiōn biblon. English]

A commentary on the first book of Euclid's Elements / Proclus; translated with introduction and notes by Glenn R. Morrow.

p. $\mathrm{cm}$.

Includes bibliographical references and index.

ISBN 0-691-02090-6

1. Mathematics, Greek. 2. Geometry-Early works to 1800.

I. Morrow, Glenn R. (Glenn Raymond), 1895-1973. II. Title.

QA31.P7413 1992

$516.2-\mathrm{dc} 20$

$92-11366$

This book has been composed in Linotype Times Roman

First Princeton Paperback printing, with a foreword by Ian Mueller, 1992

Princeton University Press books are printed on acid-free paper, and meet the guidelines for permanence and durability of the

Committee on Production Guidelines for Book Longevity of the Council on Library Resources

$\begin{array}{lllllllll}10 & 9 & 8 & 7 & 6 & 5 & 4 & 3 & 2\end{array}$

Printed in the United States of America 
TO MY WIFE

$\tau \hat{\eta} \psi v \chi \hat{\eta} \mu o v$ 
